\title{
GLUCOSE SENSOR USING CYCLIC VOLTAMMETRIC METHOD BASED ON NiO/ITO ELECTRODE
}

Serth Sedthiphonh ${ }^{1,2}$, Tran Quoc Toan ${ }^{1}$, Nguyen Van Truong ${ }^{3}$, Nguyen Quoc Dung ${ }^{\text {* }}$

${ }^{1} T N U$ - University of Education, ${ }^{2}$ Luang Prabang Teacher Training College, ${ }^{3}$ TNU - University of Technology

\begin{tabular}{|c|c|c|}
\hline \multicolumn{2}{|c|}{ ARTICLE INFO } & ABSTRACT \\
\hline Received: & $14 / 4 / 2021$ & Nickel oxide/Indium Tin Oxide (NiO/ITO) electrode was fabricated by \\
\hline Revised: & $14 / 5 / 2021$ & $\begin{array}{l}\text { electrodeposition method using the three-electrode system from } 0.1 \mathrm{M} \\
\mathrm{NiSO}_{4} \text { and } 0.1 \mathrm{M} \mathrm{H}_{2} \mathrm{SO}_{4} \text { electrolyte support solution to form } \mathrm{Ni} / \mathrm{ITO}\end{array}$ \\
\hline Published: & $20 / 5 / 2021$ & $\begin{array}{l}\text { followed by oxidation in the air to convert } \mathrm{Ni} \text { to } \mathrm{NiO} \text {. The morphology } \\
\text { and crystalline structure of } \mathrm{NiO} \text { were characterized by SEM (Scanning }\end{array}$ \\
\hline \multicolumn{2}{|l|}{ KEYWORDS } & Electron Microscope), XRD (X-Ray Diffraction), and Raman \\
\hline \multicolumn{2}{|l|}{ Nickel oxide } & $\mathrm{NiO} / \mathrm{ITO}$ electrode's electrochemical properties in the alkaline medium of \\
\hline \multicolumn{2}{|l|}{ Choronoamperomety } & $\mathrm{NaOH}$ solution and determine the glucose concentration. The conditions \\
\hline \multicolumn{2}{|l|}{ Cyclic voltammetry } & for $\mathrm{Ni}$ deposition onto ITO substrate were $0.1 \mathrm{M} \mathrm{NiSO}_{4}$, electrolyte \\
\hline \multicolumn{2}{|l|}{ Glucose sensor } & $\begin{array}{l}0.1 \mathrm{M} \mathrm{H}_{2} \mathrm{SO}_{4} \text { under deposition potential }-1.2 \mathrm{~V} \text { (vs. Ag/AgCl } \\
\text { electrode) for } 360 \text { seconds. The cyclic voltammetry (CV) }\end{array}$ \\
\hline \multirow{2}{*}{\multicolumn{2}{|c|}{ Noenzymatic }} & technique method to determine the concentration of glucose showed the \\
\hline & & $\begin{array}{l}\text { linear range detection of } 0 \text { to } 500 \mu \mathrm{M}, \mathrm{R}=0.9885 \text { with high sensitivity of } \\
2088 \mu \mathrm{Acm}^{-2} \mathrm{mM}^{-1} \text { for positive scan and } 0.5 \text { to } 13 \mathrm{mM}, \mathrm{R}=0.9966 \text { for } \\
\text { negative scan, the detection limit of } 5 \mu \mathrm{M} \text {. }\end{array}$ \\
\hline
\end{tabular}

\section{CẢM BIẾN GLUCOSE SỬ DỤNG PHƯƠNG PHÁP QUÉT THẾ VÒNG DỬA TRÊN ĐIỆN CỰC NiO/ITO}

Serth Sedthiphonh ${ }^{1,2}$, Trần Quốc Toàn ${ }^{1}$, Nguyễn Văn Truờng $^{3}$, Nguyễn Quốc Dũng $^{1 *}$

${ }^{1}$ Truò̀ng Đại học Su phạm - ĐH Thái Nguyên, ${ }^{2}$ Truò̀ng Cao đẳng Su phạm Luang Prabang

${ }^{3}$ Trừ̀ng Đại học Kĩ thuật Công nghiệp - ĐH Thái Nguyên

\begin{tabular}{|c|c|c|}
\hline \multicolumn{2}{|c|}{ THÔNG TIN BÀI BÁO } & TÓM TẮT \\
\hline Ngày nhận bài: & $14 / 4 / 2021$ & Điện cực $\mathrm{NiO} / \mathrm{ITO}$ được chế tạo bằng phương pháp điện phân Ni từ \\
\hline Ngày hoàn thiện: & $14 / 5 / 2021$ & $\begin{array}{l}\text { dung dịch } \mathrm{NiSO}_{4} 0,1 \mathrm{M} \text {; với chât điện li hô trợ } \mathrm{H}_{2} \mathrm{SO}_{4} 0,1 \mathrm{M} \text { sử dụng } \\
\text { hệ ba điện cực để hình thành nên điện cưc } \mathrm{Ni} / \mathrm{ITO} \text { sau đó oxi hóa trong }\end{array}$ \\
\hline Ngày đăng: & $20 / 5 / 2021$ & không khí để chuyển $\mathrm{Ni}$ thành $\mathrm{NiO}$. Hình thái học và cấu trúc của vật \\
\hline & & liệu được đo bằng phương pháp hiển vi điện tử quét (SEM), nhiễu xạ \\
\hline \multicolumn{2}{|l|}{ TÙ KHÓA } & tia $\mathrm{X}$ (XRD) và phố Raman. Phương pháp quét thế vòng được sử dụng \\
\hline \multicolumn{2}{|l|}{ Niken oxit } & M đối với glucose và đồng thời dùng để định lượng glucose trong dung \\
\hline \multicolumn{2}{|l|}{ Choronoamperometry } & dịch. Điều kiện đế lắng đọng điện hóa Ni lên đế ITO trong dung dịch \\
\hline \multicolumn{2}{|l|}{ Quét thế vòng } & $\mathrm{NiSO}_{4} 0,1 \mathrm{M}$ : với chất điện li hỗ trợ $\mathrm{H}_{2} \mathrm{SO}_{4} 0,1 \mathrm{M}$ ở thế $-1,2 \mathrm{~V}$ (so với \\
\hline \multicolumn{2}{|l|}{ Cảm biến glucose } & điện cực so sánh bạc/bạc clorua trong $\mathrm{KCl}$ bão hòa) với thời gian 360 \\
\hline \multirow{2}{*}{\multicolumn{2}{|c|}{ Phi enzyme }} & giây. Phương pháp quét thê vòng xác định nông độ glucose trong dung \\
\hline & & $\begin{array}{l}\text { dịch cho thây khoang tuyên tính từ } 0 \text { đên } 500 \mu \mathrm{M}, \mathrm{R}=0,9885 \text { độ nhạy } \\
2088 \mu \mathrm{Acm}^{-2} \mathrm{mM}^{-1} \text { cho chiều quét dương và từ } 0,5 \text { đến } 13 \mathrm{mM}, \mathrm{R}= \\
0,9966 \text { cho chiều quét âm, giới hạn phát hiện } 5 \mu \mathrm{M} \text {. }\end{array}$ \\
\hline
\end{tabular}

DOI: $\underline{\text { https://doi.org/10.34238/tnu-jst.4337 }}$

\footnotetext{
* Corresponding author. Email: dungnq@tnue.edu.vn
} 


\section{Introduction}

$\mathrm{NiO}$ is one of the materials that have many of these applications today, such as gas sensors [1], [2], supercapacity [3] - [5], magnetism [6], [7], etc., in which the electrochemical glucose sensor is one of the fields which have been interested and attracts many researchers. Glucose sensor plays an important role in the diagnosis of diabetes by signaling high levels of glucose in the blood [8], [9]. The glucose electrochemical sensor makes it portable, easy to fabricate, and usable at home, so it plays a big role in rapid diagnosis and continuous monitoring [8]. Although the enzymatic glucose biosensor has evolved to the third generation, the limitations of the enzyme electrode due to the nature of the enzyme are susceptible to denaturation by temperature, $\mathrm{pH}$, and required stored at low temperature and complex enzyme immobilization process that prevented the application of it in the real sample. Therefore, the nonenzymatic glucose sensor was introduced as the fourth generation glucose sensor to overcome these limitations [10]. Materials with electrochemical catalytic activities have been focused on studying, such as novel metals $\mathrm{Pt}, \mathrm{Au}$, and $\mathrm{Pd}$ [11] - [13], transition metals $\mathrm{Ni}, \mathrm{Cu}$ [14], [15] and compound of them $\mathrm{CuO}$, $\mathrm{NiO}, \mathrm{CuS}$ [8], [9], [16], [17]. However, although novel metals have high sensitivity, the electrode is poisoned by the environment and slow reaction kinetics. In contrast, the $\mathrm{Cu}$ and $\mathrm{Ni}$ metal-based electrodes show high sensitivity, but they are susceptible to toxicity by chloride ions [10]. $\mathrm{NiO}$ is one of the materials that has overcome these problems and is highly sensitive, inexpensive, and easy to fabricate. There is much research focusing on $\mathrm{NiO}$ materials because of various fabrication methods such as the sputtering method, hydrothermal [18], [19], etc. However, in order to form an electrode, it is necessary to have $\mathrm{NiO}$ fixed on the conductive substrate to ensure good adhesion and stability. Therefore, in this study, we directly create Ni film on ITO conductive substrate by electrolysis method using the three-electrode system from $0.1 \mathrm{M} \mathrm{NiSO}_{4}$ solution in $0.1 \mathrm{M} \mathrm{H}_{2} \mathrm{SO}_{4}$ support electrolyte followed by oxidation in the air to convert $\mathrm{Ni}$ to $\mathrm{NiO}$ and use the made NiO/ITO electrodes that are used in glucose electrochemical sensors without the use of enzymes.

\section{Experimental method}

\subsection{Chemicals and apparatus}

Chemicals of glucose, $\mathrm{NiSO}_{4} \cdot 6 \mathrm{H}_{2} \mathrm{O}$ (the purity of $98 \%$ ), concentrated $\mathrm{H}_{2} \mathrm{SO}_{4}$ were purchased from Sigma-Aldrich company. Other solvents such as ethanol and acetone were purchased from Xilong Chemical Company, China. Twice distilled water was distilled from STUART A4000D. The ITO substrates were cut into dimensions of $0.5 \times 2 \mathrm{~cm}$ and then ultrasonic vibrating in turn in water, ethanol, and acetone solvents to clean the substrate surface. The potentiostat galvanostat machine the Autolab $302 \mathrm{~N}$ was connected to the three-electrode system including the working electrode as the research electrode, platinum sheet as the counter electrode, and $\mathrm{Ag} / \mathrm{AgCl}$ electrode $(\mathrm{Ag}, \mathrm{AgCl} \mid$ saturated $\mathrm{KCl})$ as the reference electrode. The above device was used to fabricate electrodes as well as investigate the electrochemical properties of glucose for research electrodes. The crystalline structure and the morphology of the NiO onto the ITO substrate were characterized by X-ray diffraction (XRD, Bruker D8 Advance diffractometer) and scanning electron microscope (SEM, Hitachi S-4800), respectively.

\subsection{Preparation of NiO/ITO electrode}

$\mathrm{Ni}$ was deposited onto ITO substrate using electrodeposition at the potential of $-1.2 \mathrm{~V}$ (vs. $\mathrm{Ag} / \mathrm{AgCl}$ ) from the solution of $0.1 \mathrm{M} \mathrm{NiSO}_{4}$ and $0.1 \mathrm{M} \mathrm{H}_{2} \mathrm{SO}_{4}$ as supporting electrolyte using three-electrode systems in which ITO acted as the working electrode in Autolab 302N machine to form $\mathrm{Ni} / \mathrm{ITO}$ electrode. After that, Ni/ITO electrode was cleaned with distilled water followed by oxidation at $400{ }^{\circ} \mathrm{C}$ in the air for 2 hours to form NiO/ITO electrode. An epoxy layer was covered partially to the electrode surface to fix the area of $0.5 \times 0.5 \mathrm{~cm}\left(0.25 \mathrm{~cm}^{2}\right)$ of the working area. 


\section{Results and discussion}

\subsection{The morphology and structure of the material}

Figure 1 (a) presents the morphology of $\mathrm{NiO}$ onto ITO substrate that indicate the nano-size of $\mathrm{NiO}$ particle around $30 \mathrm{~nm}$ diameter. Figure 1 (b) shows XRD of NiO onto ITO substrate with atomic planes of (200) and (220) while the index of * belongs to ITO substrate.
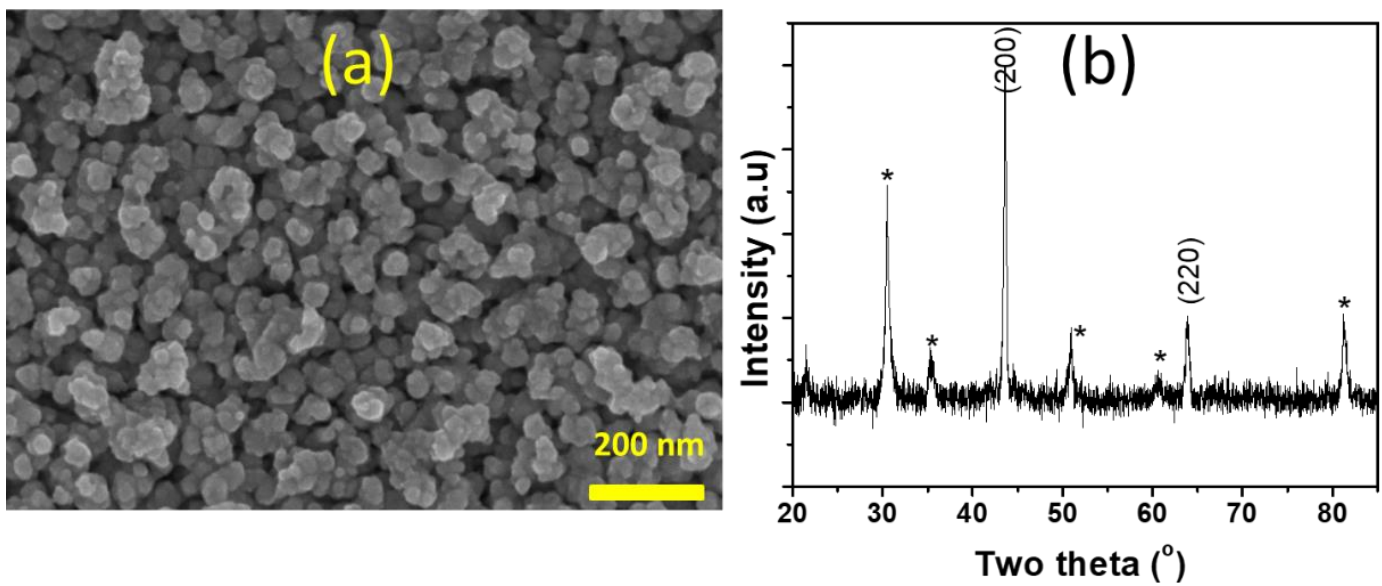

Figure 1. (a) SEM image and (b) XRD pattern of NiO onto ITO substrate

Using the Scherrer formula, the average crystallite size, $\mathrm{L}$, is:

$$
L=\frac{K \lambda}{\beta \cos \theta}
$$

where $\lambda$ is the $\mathrm{X}$-ray wavelength in nanometer (nm), in this case $\lambda=0.154, \beta$ is the peak width of the diffraction peak profile at half maximum height from Figure 1 (b) of the plane (200), $K$ is a constant related to crystallite shape, normally taken as 0.89 . The angle value $\theta$ is $19.9\left({ }^{\circ} \mathrm{C}\right)$ corresponding to the highest peak of the plane (200).

As a result, $L=25.3 \mathrm{~nm}$ was near the value observed in the SEM image. This result may suggest that each particle has a monocrystalline structure.

\subsection{Effect of electrolyte solution on electrolysis at ITO electrode}

The electrolysis process of Ni precipitation on ITO substrates was investigated through a CV scan from $+0.8 \mathrm{~V}$ to $-2 \mathrm{~V}$ with a scan rate of $20 \mathrm{mV} / \mathrm{s}$ when immersing the ITO substrate in 0.1 $\mathrm{M} \mathrm{NiSO}_{4}$ solution with supporting electrolyte $0.1 \mathrm{M} \mathrm{H}_{2} \mathrm{SO}_{4}$. Results are shown in Figure 2.

Figure 2 shows that there was almost no current at a negative scan from $+0.8 \mathrm{~V}$ until the cathode current (negative current) appeared at about $-0.9 \mathrm{~V}$, the cathode current rapidly increased and almost saturated at about $1.2 \mathrm{~V}$. At inverse scan (positive scan), cathode current decreased and almost zero at about $-0.6 \mathrm{~V}$ that much lower compared to positive scan. It can be explained that at the negative scan, the electrode was ITO, but at the positive scan, the electrode was $\mathrm{Ni} / \mathrm{ITO}$. At a potential of about $-0.4 \mathrm{~V}$, the anode current appeared and achieved a maximum at the potential of $+0.1 \mathrm{~V}$ and $+0.3 \mathrm{~V}$ with a smaller current. The peak at $+0.1 \mathrm{~V}$ may be related to the dissolution of $\mathrm{Ni}\left(\mathrm{Ni} \rightarrow \mathrm{Ni}^{2+}+2 \mathrm{e}\right)$ that the value reported in [20] with nearly the same condition of $\mathrm{pH}$ of the electrolyte solution (CV of PANI in $0.5 \mathrm{M} \mathrm{NiSO}_{4} ; 0.1 \mathrm{M} \mathrm{H}_{2} \mathrm{SO}_{4}$ ) was 0.2 $\mathrm{V}$ and in [21] with $\mathrm{pH}$ of 1.2 of it (CV of p-silicon in $5 \mathrm{M}$ fluoride aqueous solution of $\mathrm{pH} 1.2$; $50 \mathrm{mM} \mathrm{NiSO})_{4}$ was about $+0.0 \mathrm{~V}$. The higher potential peak at $+0.3 \mathrm{~V}$ may be related to water electrolysis $\left(2 \mathrm{H}_{2} \mathrm{O} \rightarrow 4 \mathrm{H}^{+}+\mathrm{O}_{2}+4 \mathrm{e}\right)$ due to the easier oxidation of $\mathrm{Ni}$ than that of water. Based on the characters of electrodeposition of Ni on ITO using investigating $\mathrm{CV}$ above, the potential of $-1.2 \mathrm{~V}$ was selected to deposit $\mathrm{Ni}$ on ITO in chronoamperometry technique. 


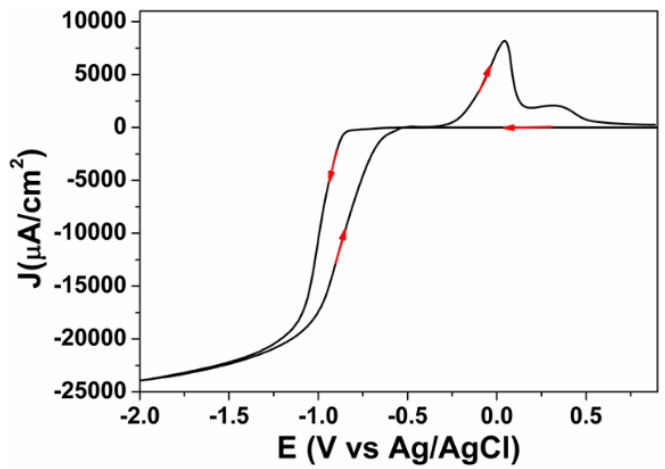

Figure 2. The $\mathrm{CV}$ of the ITO electrode in a solution of $0.1 \mathrm{M} \mathrm{NiSO}_{4} ; 0.1 \mathrm{M} \mathrm{H}_{2} \mathrm{SO}_{4}$

\subsection{Electrochemical properties of $\mathrm{NiO} / \mathrm{ITO}$ electrode to glucose in $0.1 \mathrm{M} \mathrm{NaOH}$}

The CV of NiO/ITO electrode in $0.1 \mathrm{M} \mathrm{NaOH}$ with different scan rates and plot the anode current and cathode current vs. the square root of scan rate is shown in Figure 3. The linearity of peak current proved the diffusion-controlled kinetics of the $\mathrm{CV}$ reaction at the electrode.
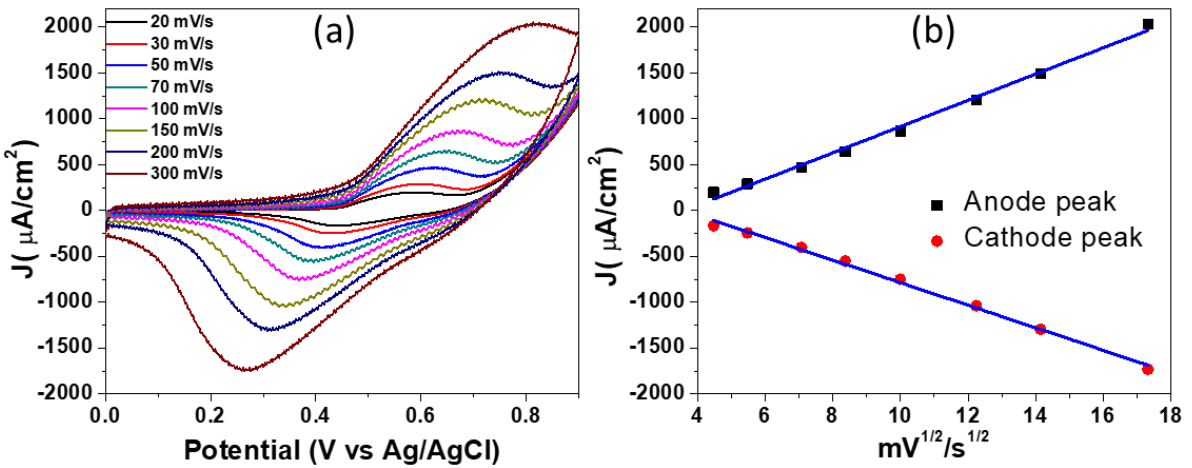

Figure 3. (a) $\mathrm{CV}$ of $\mathrm{NiO/ITO}$ electrode (for deposition time of $360 \mathrm{~s}$ ) in $0.1 \mathrm{M} \mathrm{NaOH}$ and $(b)$ cathode current $v s$. the square root of scan rate

Figure 4 (a) shows $\mathrm{CV}$ of $\mathrm{NiO} / \mathrm{ITO}$ electrode in $0.1 \mathrm{M} \mathrm{NaOH}$ with different glucose concentrations $(0 ; 0.5 ; 1 ; 2 ; 3 ; 4 ; 5 \mathrm{mM})$. Separating positive scan and negative scan is shown in Figure (b) and (c), respectively.
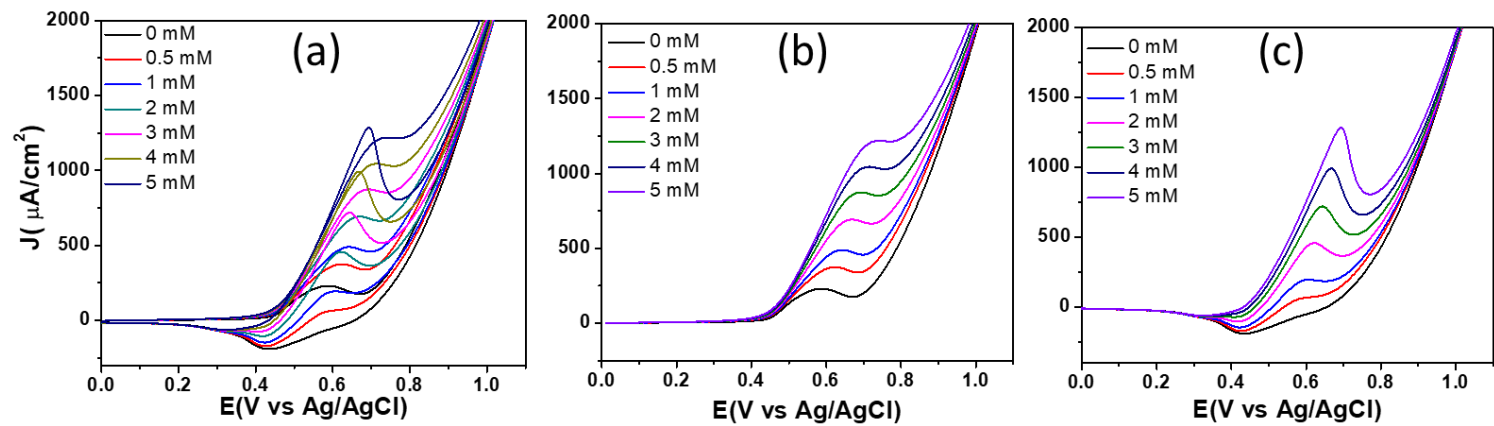

Figure 4. The $\mathrm{CV}$ of NiO/ITO electrode (with Ni electrodeposition time of $360 \mathrm{~s}$ ) in $0.1 \mathrm{M} \mathrm{NaOH}$ with different glucose concentration 
The current density increases vs. the increase of glucose concentration proved the oxidation of glucose at the electrode. As seen at the negative scan, the oxidation peak was sharper than the positive peak at higher glucose concentration (higher $0.5 \mathrm{mM}$ ) but less sharpness than that at lower concentration $(0.5 \mathrm{mM})$. In order to optimize the Ni electrodeposition time, the NiO/ITO electrodes with different time of $\mathrm{Ni}$ electrodeposition times of $60 ; 120 ; 180 ; 360 ; 600$ seconds were fabricated. Figure 5 performs the $\mathrm{CV}$ of these electrodes in $0.1 \mathrm{M} \mathrm{NaOH}$ with different glucose concentrations and shows the results in the negative scan.

As can be seen, in Figure 5 (a-e), it was found that the current density of glucose oxidation increased with the increase of glucose concentration and the oxidation potential peak tended to shift to more positive potential. This trend can be explained that the reaction products accumulated on the electrode surface at high concentrations leading to higher glucose oxidation potential.

Figure 5 (f) shows that the slope of the dependent oxidation peak current density on glucose concentration was maximum for the sample fabricated at $\mathrm{Ni}$ electrodeposition time of 360 seconds. Therefore, the electrode position condition $\mathrm{Ni}$ with time 360 seconds was chosen as the optimal condition.
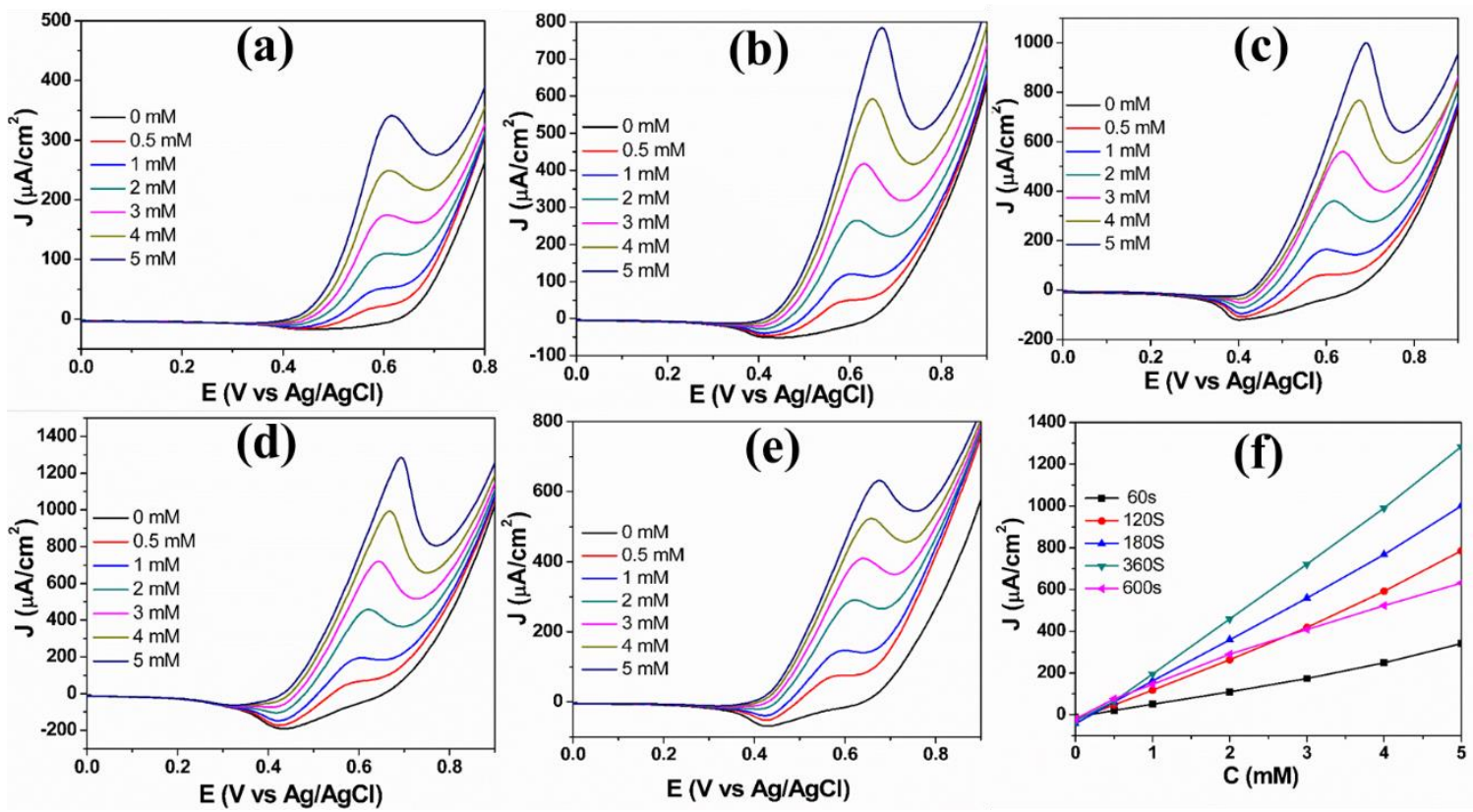

Figure 5. The $\mathrm{CV}$ of NiO/ITO electrodes in $0.1 \mathrm{M} \mathrm{NaOH}$ with different time of Ni electrodepostion $(60 ; 120 ; 180 ; 360$; and $600 \mathrm{~s})$ in negative scan $(a-e)$ and $(f)$ the plot of peak current density on glucose concentration of them

\subsection{CV technique to quantify glucose concentration in solution}

The CV of NiO/ITO electrodes (potential and time for electrodeposition of $-1.2 \mathrm{~V}$ and 360s, respectively) at different concentrations of glucose in $0.1 \mathrm{M} \mathrm{NaOH}$ solution were presented in Figure 6. As the results, in the range of glucose concentrations below $0.5 \mathrm{mM}$, the glucose oxidation peak current in the positive scan increased linearly, but at higher concentrations, the linearity was poor (Figure 6a). Whereas for the negative scan at the glucose concentration below $0.5 \mathrm{mM}$, the current did not increase significantly, but at higher concentrations, the current increased steadily, and the linearity was very wide (Figure 6b). Therefore, we constructed two standard curves, one with a positive scan peak current at a glucose concentration of 0 to $0.5 \mathrm{mM}$ and one for a peak current in the negative scan at a glucose concentration of $0.5 \mathrm{mM}$ and higher. The sensitivity was calculated from the slope of the calibration curve results in the linear range of 
$0 \mu \mathrm{M}$ to $500 \mu \mathrm{M}$, the sensitivity of $2088 \mu \mathrm{Acm}^{-2} \mathrm{mM}^{-1}, \mathrm{R}=0.9885$, and the wide linear range of $0.5 \mathrm{mM}$ to $13 \mathrm{mM}$, the sensitivity of $165.5 \mu \mathrm{Acm}^{-2} \mathrm{mM}^{-1}, \mathrm{R}=0.9966$. The detection limit estimated via a signal to noise equal to 3 was $5 \mu \mathrm{M}$. Comparison with the results of previous studies of $\mathrm{CuO}$ and $\mathrm{NiO}$ in glucose sensor (Table 1) shows that this result is good for the synthesis of $\mathrm{NiO}$ nanoparticle by simple method but high effectiveness such as the sensitivity and wide linear range.
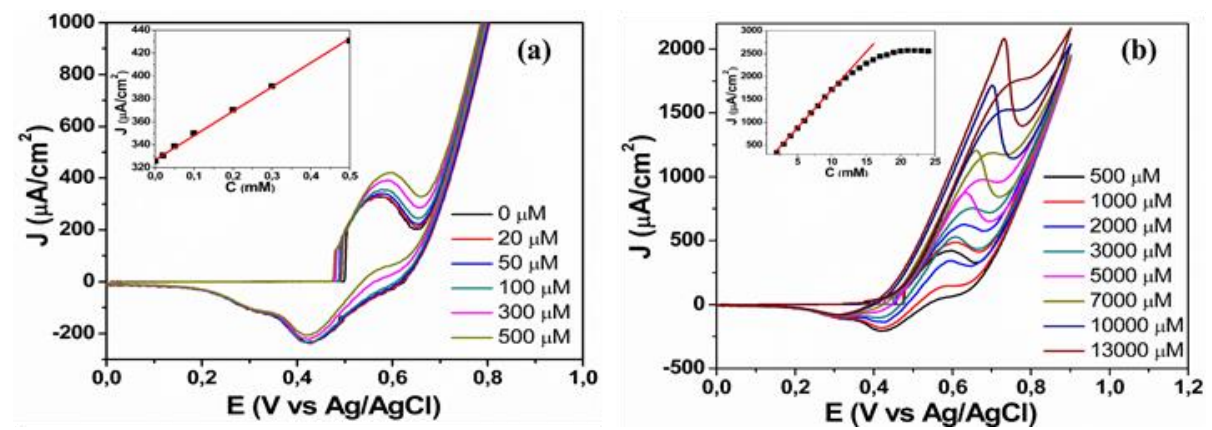

Figure 6. The CV of NiO/ITO in $0.1 \mathrm{M} \mathrm{NaOH}$ at different glucose concentration: (a) concentration of 0 to $0.5 \mathrm{mM}$, insert Figure (a) plot the peak current on glucose concentration; b) concentration of higher 0.5 mM to $1.3 \mathrm{mM}$; insert Figure (b) plot the peak current on glucose concentration

Table 1. Analytical parameters obtained for different glucose sensors

\begin{tabular}{lcccccc}
\hline \multicolumn{1}{c}{ Electrode } & Electrolyte & $\begin{array}{c}\text { Applied } \\
\text { potentia } \\
\mathbf{l}(\mathbf{V})\end{array}$ & $\begin{array}{c}\text { Linear } \\
\text { range } \\
(\boldsymbol{\mu M})\end{array}$ & $\begin{array}{c}\text { Limit of } \\
\text { detection } \\
(\boldsymbol{\mu M})\end{array}$ & $\begin{array}{c}\text { Sensitivity } \\
\left(\boldsymbol{\mu} \mathbf{A c m}^{-2} \mathbf{m M}^{-\mathbf{1}}\right)\end{array}$ & Ref. \\
\hline \multicolumn{1}{c}{$\mathrm{CuO} \mathrm{NPs}$} & $0.1 \mathrm{M} \mathrm{NaOH}$ & $\mathrm{CV}$ & $10-4000$ & 3 & 848.86 & {$[8]$} \\
$\mathrm{CuO} / \mathrm{SWCNTs}$ & $0.1 \mathrm{M} \mathrm{NaOH}$ & +0.45 & $0.05-1800$ & 0.05 & 1610 & {$[10]$} \\
$\mathrm{NiO} / \mathrm{SWCNTs}$ & $0.1 \mathrm{M} \mathrm{NaOH}$ & +0.5 & $1-1000$ & 1 & 907 & {$[22]$} \\
$\mathrm{NiO} / \mathrm{CuO} / \mathrm{PANI}$ & $0.1 \mathrm{M} \mathrm{NaOH}$ & +0.6 & $20-5000$ & 2 & - & {$[23]$} \\
$\mathrm{NiO} / \mathrm{GNS}$ & $0.1 \mathrm{M} \mathrm{NaOH}$ & +0.5 & $5-4200$ & 5 & 667.71 & {$[24]$} \\
$\mathrm{Ni} / \mathrm{NiO} / \mathrm{CNTs}$ & $0.1 \mathrm{M} \mathrm{NaOH}$ & +0.53 & $8-1500$ & - & 636.08 & {$[25]$} \\
& & & $2000-5000$ & & 284.58 & \\
$\mathrm{CuO} / \mathrm{ITO}$ film & $0.1 \mathrm{M} \mathrm{NaOH}$ & +0.45 & $1-3600$ & 0.61 & 283.6 & {$[26]$} \\
$\mathrm{CuO} / \mathrm{ITO}$ & $0.1 \mathrm{M} \mathrm{NaOH}$ & $\mathrm{CV}$ & $0-3000$ & 20 & 470.6 & {$[27]$} \\
$\mathrm{CuO} / \mathrm{ITO}$ & $0.1 \mathrm{M} \mathrm{NaOH}$ & +0.5 & $10-4200$ & 10 & 303.13 & {$[28]$} \\
$\mathrm{NiO} / \mathrm{ITO}$ & $0.1 \mathrm{M} \mathrm{NaOH}$ & $\mathrm{CV}$ & $0-500$ & 5 & 2088 & This \\
& & & $500-13000$ & & 165.5 & work \\
\hline
\end{tabular}

\section{Conclusion}

$\mathrm{NiO} / \mathrm{ITO}$ electrode was fabricated by electrodeposition of $\mathrm{Ni}$ from the solution containing 0.1 $\mathrm{M} \mathrm{NiSO}_{4}$ and $0.1 \mathrm{M} \mathrm{H}_{2} \mathrm{SO}_{4}$ at a potential of $-1.2 \mathrm{~V}$ (V vs. $\mathrm{Ag} / \mathrm{AgCl}$ ) in $360 \mathrm{~s}$. The $\mathrm{CV}$ was utilized to investigate the electrode's electrochemical properties and used to quantify glucose concentration in a solution by establishing the standard derivation curve. The NiO/ITO electrode exhibited high sensitivity of $2088 \mu \mathrm{Acm}^{-2} \mathrm{mM}^{-1}$ with a linear range of 0 to $500 \mu \mathrm{M}$ (using positive scan), the detection limit of $5 \mu \mathrm{M}$; the sensitivity of $165.5 \mu \mathrm{Acm}^{-2} \mathrm{mM}^{-1}$ (using negative scan) with a linear range of $0.5 \mathrm{mM}$ to $13 \mathrm{mM}$.

\section{REFERENCES}

[1] U.T. Nakate, R. Ahmad, P. Patil, Y. Yu, and Y.B. Hahn, "Ultra thin NiO nanosheets for high performance hydrogen gas sensor device," Applied Surface Science, vol. 506, pp. 144971, 2020. 
[2] Q. Zhou, W. Zeng, W. Chen, L. Xu, R. Kumar, and A. Umar, "High sensitive and low-concentration sulfur dioxide $\left(\mathrm{SO}_{2}\right)$ gas sensor application of heterostructure NiO-ZnO nanodisks," Sensors and Actuators B: Chemical, vol. 298, pp. 126870, 2019.

[3] T. Liu, L. Zhang, B. Cheng, W. You, and J. Yu, "Fabrication of a hierarchical NiO/C hollow sphere composite and its enhanced supercapacitor performance," Chemical Communications, vol. 54, pp. 3731 - 3734, 2018. .

[4] W. Sun, L. Xiao, and X. Wu, "Facile synthesis of NiO nanocubes for photocatalysts and supercapacitor electrodes," Journal of Alloys and Compounds, vol. 772, pp. 465 - 471, 2019.

[5] S. Xiong, S. Jiang, J. Wang, H. Lin, M. Lin, S. Weng, et al., "A high-performance hybrid supercapacitor with $\mathrm{NiO}$ derived $\mathrm{NiO} @ \mathrm{Ni}-\mathrm{MOF}$ composite electrodes," Electrochimica Acta, vol. 340, pp. 135956, 2020.

[6] K. Amemiya and M. Sakamaki, "Effect of Electric Field on Magnetism of Ni Thin Films via Antiferromagnetic NiO," e-Journal of Surface Science and Nanotechnology, vol. 16, pp. 186 - 189, 2018.

[7] M. Sakamaki and K. Amemiya, "Effect of interface $\mathrm{NiO}$ layer on magnetism in $\mathrm{Fe} / \mathrm{BaTiO}_{3}$ thin film," Japanese Journal of Applied Physics, vol. 57, pp. 0902B9, 2018.

[8] N. Q. Dung, T. T. T. Duong, T. D. Lam, D. D. Dung, N. N. Huy, and D. V. Thanh, "A simple route for electrochemical glucose sensing using background current subtraction of cyclic voltammetry technique," Journal of Electroanalytical Chemistry, vol. 848, pp. 113323-8, 2019.

[9] N. Q. Dung, T. T. T. Duong, T. D. Lam, D. D. Dung, N. N. Huy, and D. V. Thanh, "CommunicationA Simple Empirical Method for Determination of $\mathrm{CuOOH} / \mathrm{CuO}$ Redox Couple in Electrochemical Nonenzymatic Glucose Sensing," Journal of The Electrochemical Society, vol. 168, pp. 017506, 2021.

[10] N. Q. Dung, D. Patil, H. Jung, and D. Kim, "A high-performance nonenzymatic glucose sensor made of CuO-SWCNT nanocomposites," Biosensors and Bioelectronics, vol. 42, pp. 280 - 286, 2013.

[11] Y.H. Wei, C.K. Hsieh, and F.G. Tseng, "Highly-sensitive non-enzymatic glucose sensor via nano platinum crystals fabricated by phase-controlled electrochemical deposition," Journal of The Electrochemical Society, vol. 165, pp. B48, 2018.

[12] G.X. Zhong, W.X. Zhang, Y.M. Sun, Y.-Q. Wei, Y. Lei, H.P. Peng, et al., "A nonenzymatic amperometric glucose sensor based on three dimensional nanostructure gold electrode," Sensors and Actuators B: Chemical, vol. 212, pp. 72 - 77, 2015.

[13] J. S. Ye, C. W. Chen, and C. L. Lee, "Pd nanocube as non-enzymatic glucose sensor," Sensors and Actuators, B: Chemical, 208, pp. 569 - 574, 2015.

[14] S. Marini, N. Ben Mansour, M. Hjiri, R. Dhahri, L. El Mir, C. Espro, et al., "Non-enzymatic Glucose Sensor Based on Nickel/Carbon Composite," Electroanalysis, vol. 30, pp. 727 - 733, 2018.

[15] H. Chen, G. Fan, J. Zhao, M. Qiu, P. Sun, Y. Fu, et al., "A portable micro glucose sensor based on copper-based nanocomposite structure," New Journal of Chemistry, vol. 43, pp. 7806 - 7813, 2019.

[16] R. Ahmad, M. Khan, N. Tripathy, M. I. R. Khan, and A. Khosla, "Hydrothermally Synthesized Nickel Oxide Nanosheets for Non-Enzymatic Electrochemical Glucose Detection," Journal of The Electrochemical Society, vol. 167, pp. 107504, 2020.

[17] M. Cao, H. Wang, P. Kannan, S. Ji, X. Wang, Q. Zhao, et al., "Highly efficient non-enzymatic glucose sensor based on CuxS hollow nanospheres," Applied Surface Science, vol. 492, pp. 407 - 416, 2019.

[18] P. Salunkhe, M. A. AV, and D. Kekuda, "Investigation on tailoring physical properties of Nickel Oxide thin films grown by dc magnetron sputtering," Materials Research Express, vol. 7, pp. 016427, 2020.

[19] K. Nguyen, N. D. Hoa, C. M. Hung, D. T. T. Le, N. V. Duy, and N. V. Hieu, "A comparative study on the electrochemical properties of nanoporous nickel oxide nanowires and nanosheets prepared by a hydrothermal method," RSC advances, vol. 8, pp. 19449 - 19455, 2018.

[20] T. Trung, T. H. Trung, and C. S. Ha, "Preparation and cyclic voltammetry studies on nickelnanoclusters containing polyaniline composites having layer-by-layer structures," Electrochimica Acta, vol. 51, pp. 984-990, 2005.

[21] P. Gorostiza, M. A. Kulandainathan, R. Díaz, F. Sanz, P. Allongue, and J. R. Morante, "Charge Exchange Processes during the Open-Circuit Deposition of Nickel on Silicon from Fluoride Solutions," Journal of The Electrochemical Society, vol. 147, pp. 1026-1030, 2000. 
[22] N. Q. Dung, D. Patil, H. Jung, J. Kim, and D. Kim, "NiO-decorated single-walled carbon nanotubes for high-performance nonenzymatic glucose sensing," Sensors and Actuators, B: Chemical, vol. 183, pp. $381-387,2013$.

[23] K. Ghanbari and Z. Babaei, "Fabrication and characterization of non-enzymatic glucose sensor based on ternary NiO/CuO/polyaniline nanocomposite," Analytical biochemistry, vol. 498, pp. 37 - 46, 2016.

[24] G. Zeng, W. Li, S. Ci, J. Jia, and Z. Wen, "Highly dispersed NiO nanoparticles decorating graphene nanosheets for non-enzymatic glucose sensor and biofuel cell," Scientific reports, vol. 6, pp. 1-8, 2016.

[25] H. Yin, J. Zhu, J. Chen, J. Gong, and Q. Nie, "MOF-derived in situ growth of carbon nanotubes entangled $\mathrm{Ni} / \mathrm{NiO}$ porous polyhedrons for high performance glucose sensor," Materials Letters, vol. 221, pp. 267 - 270, 2018.

[26] T. T. T. Duong, N. Q. Dung, T. D. Lam, P. H. Chuyen, and N. T. Dai, "Facile synthesis of CuO/ITO film via the chronoamperometric electrodeposition for nonenzymatic glucose sensing," Communications in Physics, vol. 30, pp. 161-170, 2020.

[27] N. Q. Dung, D. T. Huong, N. V. Tien, and N. H. Nhung, "A cyclic voltage method for glucose electrochemical sensor based on CuO/ITO electrode," Journal of Physical, Chemical and Biological analysis, (in Vietnamese), vol. 22, pp. 98-105, 2017.

[28] T. T. T. Duong, N. Q. Dung, and T. D. Lam, "Chronoamperometry technique in glucose sensor based on CuO/ITO electrode," Journal of Chemistry, (in Vietnamese), vol. 56 (3E12), pp. 15-20, 2018. 